\title{
VIGS EN MENSLIKE GEDRAG: 'N TEOLOGIES-ETIESE BEOORDELING
}

\author{
P.J. de Bruyn \\ Departement Etiek \\ Poichefstronmse Universiteit vir CHO \\ POTCHEFSTROOM
}

\begin{abstract}
Abstrac
AIDS is a fatal disease which is at present incurable. II is spread mainly through extra-marital heterosemal and homoserual intencourse. The distinctive feature of AIDS is that it destroys the immunity system of the human body. The victinu subsequently dies of any common disease. At present AIDS is spreading extremely rapidly: world-wide, the number of people contracting the disease is doubled every ten months.

The most important ways in which AIDS is contracted and spread, can be ascribed 10 sinful actions and ways of living because these patterns of conduct an fortidden by Gad. Firstly, this means that if sexual intercourse were practised within lawful matrimony according to God's will, AlDS would not be a threat of any signifance. Secondhy, it means that people contracting AIDS through o promiscuous lifestyle, should see the disease as a punishment of God. In those instances where AIDS is contracted in other ways, it should be regarded as a sone trial.

AIDS sufferers should not be stigmatised or astracised, bul should be actively supported and helped, especially by the chunches. The way in which Christians behave towands sufferers of AIDS should reflect the compassion and charity of Christ towards sinners.
\end{abstract}

\section{INLEIDING}

1.1 Objek

By 'n studie van die verhouding tussen VIGS en menslike gedrag, is dit belangrik om van die volgende sake kennis te neem:

- VIGS is die afkorting vir verworwe immuniteitsgebreksindroom;

- VIGS is 'n dodelike siekte waarvoor daar tans nog geen geneesmiddel is nie;

* VIGS word hoofsaaklik deur buite-egtelike seksuele omgang versprei;

* daar is reeds baie mense wat VIGS opgedoen het,nie slegs deur buite-egtelike geslagsgemeenskap nie, maar ook op ander maniere soos bloedoortappings, die gebruik van onhigiëniese inspuitnaalde, die geboorte uit 'n moeder wat 'n draer 
van die VIGS-virus is, die drink van moedersmelk van 'n vrou wat VIGS het, ensovoorts;

- volgens tans bestaande kennis is dit baie onwaarskynlik dat VIGS deur normale menslike kontak soos met die hand groet, die gebruik van dieselfde eetgereedskap, die gebruik van dieselfde beker aan die Nagmaalstafel, die aantrek van mekaar se klere, die gebruik van dieselfde toilette, ensovoorts oorgedra kan word. (Vgl. Jansen, 1990:0-11.)

Die objek wat in hierdie studie behandel gaan word, is:

* die verspreiding van VIGS deur buitehuwelikse seksuele omgang, homoseksueel en heteroseksueel en, in aansluiting daarby, die vraag of VIGS gesien moet word as 'n straf van God;

* die gedrag van mense teenoor VIGS-lyers, en in die besonder, die roeping van die kerke in dié verband.

\subsection{Doel}

Die doel van hierdie studie is om laasgenoemde twee vorms van menslike gedrag te beoordeel volgens die beginsels en norme van die teologiese etiek. Dit beteken dus dat genoemde gedragswyses in die lig van God se Woord beoordeel moet word.

\section{$1.3 \quad$ Aktualiteit}

Die etiese beoordeling van persone wat VIGS opgedoen het en bydra tot die verspreiding daarvan én die gedrag van ander mense teenoor hulle is tans baie aktueel. Dit is ook vanselfsprekend in die lig van die feit dat VIGS vir die hele mensdom wêreldwyd 'n erpstige bedreiging is. Behalwe boeke wat daaroor verskyn het, is daar in verskillende populêre en wetenskaplike tydskrifte 'n stroom artikels gepubliseer waarin aan etiese aspekte van VIGS aandag gegee is. (Vgl. o.a. Anon, 1989; Bennett \& Bennett, 1989; D'Assonville, 1989; Den Toom, 1988a, 1988b; Douma, 1987; Hartmann, 1987; Louw, 1988; Pienaar, 1989/90; Shelp \& Sunderland, 1987; Sunderland \& Shelp, 1987; Van Wyk, 1990; Wouters, 1987.)

\subsection{Maatstaf}

Die maatstaf wat vir die beoordeling van die mens se optrede in hierdie studie aangewend word, is die geopenbaarde wil van God soos dit gevind word in sy Woord en soos 
daaraan gestalte gegee word in die belydenisskrifte.

Die grond en motivering vir hierdie uitgangspunt is geleë in die belydenis dat die Heilige Skrif in sy geheel en in sy dele die onfeilbare Woord van God is (Nederlandse Geloofsbelydenis artt. 3,5,7).

Vir die etiek wat te doen het met die beoordeling van die mens se handel en wandel, is die uitgangspunt van besondere belang. Dit beteken dat ook die etiese direktiewe in die Skrif goddelike gesag het en dat die mens, en in die besonder die Christen, verplig is om hom daaraan te onderwerp en daardeur te laat lei.

As die Skrif in die etiek as maatstaf aangewend word, moet dit geskied volgens die hermeneutiese reels wat aan die Skrif in sy geheel en in sy onderskeie dele reg laat geskied sonder dat bogenoemde belydenisuitgangspunt in gedrang kom.

Die hermeneutiese reels waarvolgens die Skrif in hierdie artikel verklaar sal word, is in hoofsaak dié wat aangedui word in die werke van Grosheide (1929) en Greijdanus (1946) en in die besonder in die artikel van Coetzee, De Klerk en Floor (1980:12-26).

\subsection{Werkplan}

Eers sal die oorsprong, verspreiding, aard en omvang van VIGS kortliks aangedui word. Daarna sal die twee sake wat in punt 1.1 genoem is, eties beoordeel word. Aan die einde sal by wyse van samevatting enkele etiese konsekwensies van VIGS aangedui word. Die roeping van die kerke in die huidige situasie ten opsigte van op VIGS sal ook behandel word.

\section{DIE OORSPRONG, VERSPREIDING, AARD EN OMVANG VAN VIGS}

\subsection{Die oorsprong en verspreiding van VIGS}

VIGS is die eerste keer in 1981 in Los Angeles (VSA) gediagnoseer, eers by een en later by nog vyf jong, voorheen gesonde, homoseksuele mans (Eloff, 1989:5; Langone, 1989:31; Sunderland \& Shelp, 1987:7; Wouters, 1987:13-14).

Op ongeveer dieselfde tydstip het 26 voorheen gesonde, homoseksuele mans in New York'n soortgelyke siekte opgedoen (Eloff, 1989:5; Wouters, 1987:14). Die ernstige aard van VIGS as siekte het waarskynlik eers in 1985 tot die publiek deurgedring toe dit bekend geword het dat die bekende filmster, Rock Hudson, dit ook opgedoen het. 
Medies kon daar feitlik niks vir hom gedoen word nie en hy is oorlede. Foto's wat van hom kort voor sy dood geneem is en op televisie vertoon is, het getoon hoe hy deur die "nuwe" siekte afgetakel is. Dit het 'n groot deel van die mensdom geskok en hulle onder die indruk van die erns van hierdie siekte gebring (Shelp \& Sunderland, 1987:1112).

Volgens gegewens tans vrygestel, word aanvaar dat die VIGS-virus in Sentraal-Afrika deur groen-ape aan die mens oorgedra is. Daarvandaan het dit versprei na Haiti en Amerika en vandaar na Europa. Daar is egter aanduidings dat dit ook direk van Sentraal-Afrika na Europa versprei het en nie net via Amerika nie. Van SentraalAfrika het dit ook na die suidelike dele van Afrika versprei (Eloff, 1989:6-7; Langone, 1989:33-34).

Aanvanklik is VIGS in die VSA net by homoseksuele mans aangetref. Navorsing het egter getoon dat, voor dit na die Weste versprei het, dit in Sentraal-Afrika reeds op heteroseksuele wyse oorgedra is (Eloff, 1989?:11; Louw, 1988:67; Wouters, 1987:14).

Volgens Eloff (1989?:11) affekteer VIGS in Westerse lande "hoofsaaklik die volgende persone:

* Homoseksuele en biseksuele mans.

* Binne-aarse dwelmverslaafdes wat dieselfde naalde en spuite gebruik.

* Hemofilielyers en ander pasiënte wat besmette bloedprodukte ontvang.

* Babas van moeders wat met die virus besmet is.

* Heteroseksuele kontakte van besmette individue.

* Persone met onbekende risikofaktore".

Dit is egter duidelik dat buite-egtelike geslagsgemeenskap met verskillende persone, nie net homoseksueel nie, maar ook heteroseksueel, die vernaamste wyse van verspreiding van die VIGS-virus is (Eloff, 1989?:11; Louw, 1988:67-68; Pretorius \& Pretorius, 1987:15).

\subsection{Die kenmerkende aard van VIGS}

Die besondere kenmerk van die VIGS-virus is dat dit die liggaam se immuniteitsisteem vernietig. Dit het tot gevolg dat die persoon wat dit onder lede het se natuurlike vermoë om weerstand te bied teen infeksies en dit af te weer, drasties afneem. Eloff (1989?:5) sê van die VIGS-virus die volgende: "Die virus beskadig die immuniteitsisteem deur 'n spesifieke witbloedsel, bekend as die T-helper limfosiet (T-selle), binne te dring en te vernietig. Hierdie selle speel 'n sleutelrol in die immuniteitsisteem." Die 
gevolg is dat 'n mens, na die aftakelingsproses wat VIGS veroorsaak het, aan enige doodgewone siekte kan sterf.

Volgens Wouters (1987:15) is die VIGS-virus in werklikheid redelik swak en kwesbaar. Dit kan alleen in die bloed en ander vog van die liggaam lewe. Daarbuite sterf dit baie gou. Die moontlikheid om VIGS te kry is dus in der waarheid baie kleiner as wat die geval is met ander aansteeklike siektes soos cholera.

Dit beteken dat as VIGS nie deur geslagsgemeenskap of kontak met die bloed van 'n besmette persoon oorgedra word nie, dit feitlik geen bedreiging vir die mens sou wees nie.

\subsection{Die omvang van VIGS}

Hoewel die VIGS-virus baie swak en kwesbaar is, soos hierbo (punt 2.2) aangedui, kom 'n mens voor die paradoks te staan dat juis hierdie siekte tans ontsettend vinnig versprei. Volgens Wouters (1987:15) verdubbel die aantal mense wat VIGS opdoen elke tien maande. In 1983 is daar in die VSA 73 persone geregistreer wat VIGS opgedoen het. In 1987 het hierdie syfer gegroei na 31 000, en na verwagting sal daar in 1991270000 wees.

Dit is baie moeilik om te bepaal wat die omvang van VIGS in die sentrale en suidelike dele van Afrika is, omdat die mediese versorging in baie dele onvoldoende is en alle gevalle van VIGS nie aangemeld word nie. Kenners is egter van oordeel dat VIGSgevalle baie vinnig toeneem (Wouters, 1987:17).

Aangesien die mense wat met die VIGS-virus besmet word so vinnig toeneem en buiteegtelike seksuele omgang (homoseksueel en heteroseksueel) verreweg die vernaamste wyse van verspreiding is, toon dit aan wat die omvang van buite-egtelike geslagsgemeenskap in die wêreld is.

Verdere gegewens oor die omvang en verspreiding van VIGS word in die artikel van mnr. A.T. Viljoen elders in hierdie uitgawe verstrek (p.329-343). 
VIGS en menslike gedrag: 'n teologies-etiese beoordeling

\section{ETIESE BEOORDELING}

\subsection{Etiese beoordeling van buitehuwelikse geslagsgemeenskap}

\subsubsection{Inleiding}

In hierdie afdeling word gehandel oor buitehuwelikse geslagsgemeenskap, heteroseksueel en homoseksueel, as 'n wyse waarop VIGS opgedoen en versprei word.

Soos reeds aangedui (vgl. punt 2.3), is buitehuwelikse geslagsgemeenskap in heteroseksuele en homoseksuele vorm die vernaamste wyse waarop VIGS opgcdoen en versprei word. 'n Mens sou in die lig hiervan verwag het dat hierdie situasie tot gevolg sou hê dat mense aangespoor sou word om 'n kuise lewe binne en buite die huwelik te voer. Skynbaar het die praktyk van buitehuwelikse geslagsgemeenskap egter dermate deel van die moderne mens geword dat daar nie eers aan gedink word om mense te oorreed om daarvan af te sien nie. Die alternatief is dat buitehuwelikse seks op so 'n wyse beoefen moet word dat infeksie met die VIGS-virus soveel as moontlik uitgeskakel word. Om dié rede word advies soos die volgende gegee:

- veelvuldige of onbekende seksmaats (of albei) moet vermy word;

- oopmondsoenery moet vermy word omdat die VIGS-virus ook al in speeksel gevind is;

- $\quad$ kondome of spermdoders moet gebruik word (Langone, 1989:198-199; vgl. ook D'Assonville, 1989:6).

Den Toom (1986:11) gaan selfs so ver om te sê dat dit die taak van die Christelike etiek is om aan mense aanwysings te gee hoe om op verantwoorde wyse (buitehuwelikse - P.J. d.B.) geslagsgemeenskap te hê sonder die gevaar om met die VIGS-virus besmet te word. Daarom beskou hy die aanbeveling om kondome te gebruik as lewensreddend.

Die ironie van die saak is dat kondome wat aanvanklik bedoel was om ongewenste lewe te voorkom, nou aanbeveel word as 'n middel om ongewenste dood te voorkom (Wouters, 1987:24).

In die lig van hierdie standpunte en praktyke moet vasgestel word wat die Skrif oor heteroseksuele buitehuwelikse geslagsgemeenskap en homoseksuele geslagsgemeenskap leer. Daarna moet vasgestel word of VIGS as straf van God op seksuele oortredings gesien kan word. 


\subsubsection{Heteroseksuele buitehuwelikse geslagsgemeenskap}

Volgens die Skrif behoort geslagsgemeenskap slegs binne die huwelik as duursame verhouding plaas te vind (Gen. 2:24; 19:20-21; Deut. 22:13-29; Hoogl. 8:8-10; Matt. 1:18-25; 19:5-6 en 10-12; 1 Kor. 6:12-20; 7:7-9, 36). Geslagsgemeenskap wat buite die huwelik plaasvind, word deur die Skrif as hoerery (porneia) bestempel en skerp veroordeel (Matt. 15:19; Mark. 7:21; 1 Kor. 6:9,10; 7:2; 1 Tes. 4:3-4; De Bruyn, 1982:247-249; 283-306). Geslagsgemeenskap word dermate aan die huwelik verbind dat as 'n man en 'n vrou wat nie verloof of getroud is nie, geslagsgemeenskap het, hulle volgens die wet van Moses verplig was om met mekaar te trou ongeag of die vrou deur die geslagsgemeenskap swanger geraak het of nie (Eks. 22;16-17; Deut. 22:28-29).

Binne die huwelik as liefdesgemeenskap het geslagsgemeenskap nie net 'n plek en funksie met die oog op voortplanting nie, maar het dit ook 'n eie plek en betekenis in dié sin dat dit deur man en vrou aangevoel word as een van die belangrikste maniere waarop hulle uiting gee aan hulle besondere liefde vir en trou aan mekaar én aan die innige, wedersydse begeerte om in hulle liefde so na as moontlik aan mekaar te kom en met mekaar één te word (De Bruyn, 1982:208-211). Daarby bewys man en vrou deur geslagsgemeenskap binne die liefdesgemeenskap van die huwelik wedersyds 'n diens aan mekaar omdat hulle so bevrediging vir hulle seksuele behoeftes vind en op dié wyse mekaar beskerm teen pogings van Satan om hulle tot owerspel of ontug te verlei (1 Kor. 7:2-5; De Bruyn, 1985:6-10; 1989: 12-13).

Dit beteken dat volgens die Skrif die funksie, doel en bestemming van seks slegs binne die kaders van die huwelik te vinde is. Seks was nooit deur God bedoel om die belangrikste element van 'n genotmoraal of sportmoraal of ontspanningsmoraal buite die huwelik te wees nie.

Hieruit is dit duidelik dat geslagsgemeenskap buite die huwelik sonder enige twyfel in stryd is met God se wil. Dit beantwoord nie aan die wese en doel van geslagsgemeenskap soos dit uit die Skrif afgelei kan word nie (De Bruyn, 1982:211-236). Daarom word dit beslis afgewys en veroordeel.

\subsubsection{Homoseksuele geslagsgemeenskap}

Homoseksualiteit vord ten sterkste deur God veroordeel. In Levitikus 18:22 (1953vertaling) word gesê: "Met 'n manspersoon mag jy ook geen gemeenskap hê soos 'n mens met 'n vrou het nie. Dit is 'n gruwel." Volgens Levitikus 20:13 (1953-vertaling) bepaal die Here: "En as 'n man met 'n manspersoon gemeenskap het soos 'n mens met 'n vrou het, het altwee iets gruweliks gedoen. Hulle moet sekerlilk gedood word. 
Hulle bloedskuld is op hulle." In die Nuwe Testament word van homoseksueles gesê dat hulle nie deel het aan die koninkryk van God nie (1 Kor. 6:10; 1 Tim. 1:10). In Romeine 1:26 en 27 word homoseksuele verhoudings as "teen die natuur" veroordeel.

Sekere voorstanders van homoseksualiteit beweer dat Paulus in Romeine 1:26 en 27 gewone mans en vrouens op die oog het wie se lewens heteroseksueel gerig is. Vir hulle is homoseksuele bedrywighede teennatuurlik. Maar as mense wie se lewens homoseksueel gerig is aan homoseksuele aktiwiteite meedoen, gaan hulle nie teen hulle eie natuur in nie, maar leef hulle dan juis volgens hulle eie natuurlike neigings. Daarom is dit vir hulle nie verkeerd nie, maar doen hulle wat hulle na regte behoort te doen (Van Veen, 1972:48).

Hierdie siening is eksegeties onaanvaarbaar, omdat Paulus in Romeine 1 nie sonder meer sy uitgangspunt in die fisiese of psigiese struktuur van die mens neem nie, maar in die wil en oorspronklike bedoeling van God (Douma, 1973:60).

God het die mens as man en vrou so geskape dat hulle twee met mekaar geslagsgemeenskap kan hè (Gen 1:27; 2:24). Dit is die "natuurlike verkeer" waarvan Paulus praat. Dit is hoe geslagsgemeenskap ooreenkomstig God se wil en doel by die skepping van die mens moet plaasvind. Die sondige praktyke waarvan Paulus in Romeine 1:26-27 praat, bestaan dan ook daarin dat die deur God gestelde orde omgekeer word sodat die natuurlike geslagsverkeer van man en vrou ingeruil word vir die onnatuurlike geslagtelike omgang van vrouens met vrouens en mans met mans (Douma, 1973:5860).

Uit bovermelde is dit in elk geval baie duidelik dat homoseksualiteit teen die uitơruklike bevele van God ingaan. Hy bestempel dit as 'n gruwel, en in Israel moes die skuldiges met die dood gestraf word.

\section{Samevattende gevolgtrekkings}

Uit die behandeling van punte 3.1.2 en 3.1.3 het dit duidelik geword dat sowel die heteroseksuele buitehuwelikse geslagsgemeenskap as die homoseksuele geslagsgemeenskap in stryd is met die wil van God en daarom sonde teen Hom is. Dit beteken dat die vernaamste wyses waarop VIGS opgedoen en versprei word, sondige lewensen handelswyses is omdat dit deur God verbied word.

Hieruit is dit duidelik dat 'n mens nooit goedkoop teen God kan sondig nie. Uiteindelik moet 'n duur prys vir ' $n$ lewe in sonde betaal word. Hier geld inderdaad wat Paulus in Galasiërs 6:7 en 8 sê: "Moenie julleself mislei nie: God laat nie met Hom spot nie. 
Wat 'n mens saai, dit sal hy ook oes. Wie op die akker van die sondige natuur saai, sal van die sondige natuur dood en verderf oes."

Omgekeerd kan - in die lig van die Skrif en in die lig van die werklike stand van sake ten opsigte van die opdoen en verspreiding van VIGS - met stellige sekerheid verklaar word dat indien geslagsgemeenskap ooreenkomstig die wil van God net binne die wettige huwelik plaasvind, VIGS vir die mensdom slegs ' $n$ minimale bedreiging sal wees en 'n faktor is waarmee in die toekoms skaars rekening gehou hoef te word. Dit is selfs moontlik dat VIGS homself in so 'n situasie sal uitwoed en verdwyn. (Vgl. Verschoor, 1990:29.)

\subsubsection{VIGS en God se straf op die sonde}

\subsubsection{God se straf op die sonde}

Uit die Skrif is dit duidelik dat God dié wat sy wil misken en sy gebooie oortree, straf vir hulle sondige dade. Met verwysing na verskeie Skrifgegewens toon Velema (1978:13-19) dit baie duidelik aan. Brillenburg Wurth (1956:52) vat die Bybelse gegewens in hierdie verband saam as hy van God sê dat sy goddelike reg geen skending duld nie. Daarom moet Hy op die sonde wat teen Hom as hoogste majesteit gepleeg word, met onverbiddelike strengheid en straf reageer. Daarby kom nog dat God se straf op die sonde nie net in die toekoms sal plaasvind nie, maar heel dikwels word dit reeds in die hede aan die skuldiges voltrek (Floor, 1979:79).

God straf die sondige mens tydens sy aardse lewe nie net deur teëspoed, siekte, rampe, ensovoorts nie, maar dikwels juis deur hom uit te lewer en oor te gee aan sy eie sondige begeertes. Dit blyk veral baie duidelik uit Romeine 1:18-31. Omdat die mense God se openbaring en God se wil verwerp het, het Hy toornig geword en hulle oorgegee aan 'n onbeheerste lewe in seksuele losbandigheid (Ridderbos, 1959:46-49). Drie maal - in verse 24,26 en 28 - word die uitdrukking "God gee hulle oor ..." ten opsigte van seksuele losbandigheid gebruik (Floor, 1979:80). Dit beteken dat seksuele losbandigheid waaronder voorhuwelikse en buitehuwelikse seksuele verkeer, homoseksuele dade, huweliksontrou, ensovoorts nie net 'n sondige lewe is wat God vertoorn en wat Hy sal straf nie; nee, dit is reeds God straf (Brillenburg Wurth, 1963:114). In sy toorn het Hy die mens daarin laat tuimel sodat hy in sy eie onbeheerste welluste kan verdrink. 


\subsubsection{Die verband tussen God se straf en die sonde}

By 'n besinning oor die straf van God moet 'n mens aan die een kant waak teen wat Velema (1978:15-16) "causaliteitsdenken" noem, waaraan veral die vriende van Job hulle skuldig gemaak het. Dit is die verkeerde siening dat elke ramp of teëspoed wat 'n mens tref, beskou moet word as 'n straf van God vir 'n spesifieke sonde. Christus het hierdie siening ook afgewys in sy gesprek met sy dissipels oor die man wat blind gebore is (Joh. 9:1-3). As daar oor VIGS besin word, moet dit ook in gedagte gehou word, want nie almal wat buitehuwelikse heteroseksuele geslagsgemeenskap of homoseksuele geslagsgemeenskap het, kry VIGS nie.

Aan die ander kant kan egter nie ontken word dat daar in die straf van God dikwels 'n baie nou verband tussen die begane sonde en die straf op die spesifieke sonde is nie (Brillenburg Wurth, 1956:56). So vestig Goslinga (1956:151) die aandag daarop dat daar in Natan se strafaankondiging oor Dawid (2 Sam. 12:10-12) na sy dubbele sonde van ontug en moord, 'n samehang is tussen die aard van die straf en die sonde wat begaan is. Iets soortgelyks tref 'n mens ook aan in Job se woorde volgens Job 31:9-10 (Kroeze, 1961:345). Dieselfde word ook in die Nuwe Testament aangetref, byvoorbeeld in Matteus 10:33; Markus 8:38; Kolossense 3:25; 2 Tessalonisense 1:6 en 2 Timoteus 2:12. Dit word veral duidelik gevind in die reeds aangehaalde woorde van Paulus in Galasiërs 6:7, as hy, nadat hy gesê het: "Moenie julleself mislei nie: God laat nie met Hom spot nie", daaraan toevoeg: "Wat 'n mens saai, dit sal hy ook oes." (Vgl. Spr. 22:8; Greijdanus, 1953:150; Ridderbos, 1954:218-219; Hendriksen, 1979:236-237.)

Uit al hierdie gegewens is dit baie duidelik dat daar volgens die Skrif dikwels 'n baie nou verband is tussen die aard van die sonde en die straf van God wat daarop volg. Soms is dit ook so voor-die-hand-liggend en vanselfsprekend dat dit nie ontken kan word nie. Om byvoorbeeld die aftakeling en verwoesting van die liggaam deur dronkenskap of armoede as gevolge van verkwisting te sien as God se straf op die sonde, is nie alleen lıgies nie, maar ook Skriftuurlik verantwoord. (Vgl. Spr. 23:20,21; Jes. 5:11,22.)

\subsubsection{Siekte as straf op sonde}

In die besonder is dit uit die Skrif duidelik dat siekte soms as die straf van God op die sonde gesien moet word. Dit blyk onder andere duidelik uit Psalm 38:4 waar Dawid sê: "Deur u toorn is daar nie meer'n gesonde plek aan my liggaam nie, deur my sonde is daar nie meer 'n heel plek aan my lyf nie." In sy verklaring van hierdie vers sê $\mathrm{Nic} \mathrm{H}$. Ridderbos (1962:415) dat die digter sy ellende sien as 'n gevolg van God se toorn. En Velema (1978:14) sê van hierdie teks: "De dichter ervaart de ziekte zelf als straf op 
zijn zonde. Hij ontmoet in de moeite van zijn lijden Gods oordeel over zijn verdwaasdheid."

Hoewel Velema (vgl. supra) waarsku teen die sogenaamde "causaliteitsdenke", sê hy (1978:15-16) ook: "Men mag echter een waarschuwing tegen causaliteitsdenken niet doen uitlopen op de afwijzing van elk verband tussen zonde en lijden."

Hierdie siening is ook nie vreemd aan die Nuwe Testament nie. In 1 Korintiërs 11:27. 34 wys Paulus daarop dat daar lidmate in die kerk van Korinte is wat met ' $n$ verkeerde gesindheid en daarom op ' $n$ verkeerde wyse deelneem aan die viering van die Nagmaal. En dan sê hy in verse 29 en 30: "Want hy wat eet en drink sonder om te besef dat dit die liggaam van die Here is, bring daardeur 'n oordeel oor homself. Daarom is daar baie swakkes en sieklikes onder julle en sterf daar baie van julle."

Hierdie uitsprake van Paulus beteken volgens Grosheide (1954:146) dat die Korintiërs in die swakheid, siekte en dood van sommige lidmate die oordeel van God moet sien en daarom moet besef dat hulle hulle van hulle sondes moet bekeer. Ook $\mathrm{H}$. Ridderbos (1966:477) is dieselfde mening toegedaan, want in sy verklaring van vers 30 sê hy: "Paulus wijst het oordeel van Christus in de gemeente van Korinthe aan in het grote aantal ziekte - en sterfgevallen, dat zich onder haar voordeed."

Hoewel 'n mens dus in die lig van Johannes 9:1-3 en ander ooreenstemmende uitsprake in die Skrif nie mag sê dat elke siekte die gevolg van 'n spesifieke sonde is nie, is dit uit die Skrif wel duidelik dat sekere siektes inderdaad die gevolg van spesifieke sondes is.

\subsubsection{VIGS as God se straf op die sonde}

Kan VIGS gesien word as God se straf op die sonde van buitehuwelikse heteroseksuele en homoseksuele geslagsgemeenskap?

Om 'n antwoord hierop te kry, moet in aansluiting by dit wat in die vorige punt (3.1.4.2) gesê is, veral besin word oor Romeine 1:27. In vers 26 en die eerste deel van vers 27 word gesê dat God die skuldiges oorgee "aan skandelike drifte". Dit is die eerste deel van God se straf.

Die skandelike drifte waaraan die betrokke sondaars oorgelewer is, kom dan.tot openbaring in die beoefening van homoseksuele geslagsgemeenskap. Maar vir hierdie homoseksuele handelinge waaraan hulle dan meedoen, ontvang hulle die tweede deel van God se straf, want, sê Paulus verder in vers 27 , hulle "bring oor hulleself die 
verdiende straf vir hulle perversiteit". Verskeie Skrifverklaardes spreek dit as hulle oortuiging uit dat Paulus hier inderdaad bedoel dat die seksuele sondes in die verwoesting van die betrokkenes se liggame tot openbaring kom. (Vgl. Barnes, 1847:53; Zahn, 1910:101; Lekkerkerker, 1974:77; Hendriksen, 1980:79; D'Assonville, 1989:6.) Dit kom dus daarop neer dat die misbruik van die liggaam - in stryd met God se uitdruklike bevele - deur God gestraf word deur die aftakeling van daardie selfde liggaam wat op 'n sondige wyse so misbruik is. Ridderbos (1959:48) sê dat God in so 'n situasie die mens as mens prysgee omdat die mens God nie as God wil erken en dien nie.

Aangesien buitehuwelikse heteroseksuele en homoseksuele geslagsgemeenskap handelinge wat sondig en in stryd met God se uitdruklike bevele is - verreweg die vernaamste wyses is waarop VIGS opgedoen en versprei word, is dit in die lig van die Skrif, soos hierbo aangedui, alleen logies om ten opsigte van diegene wat VIGS op hierdie wyses opdoen, te aanvaar dat dit God se straf op hulle sondige lewe is.

'n Mens kan die verband tussen 'n sondige seksuele lewe en VIGS vergelyk met die verband tussen diefstal en gevangenisstraf as straf daarvoor. Die dief moet in die gevangenisstraf nie net die straf van mense sien nie, maar ook die straf van God. Die feit dat ander diewe daarin slaag om die gereg te ontwyk, beteken nie dat hulle oortredings kleiner en minder strafwaardig is nie. Trouens, die feit dat hulle die gereg (aanvanklik) ontwyk, kan juis tot hulle nadeel (oordeel?) wees, want dit kan water op hulle meul wees om met hulle bose dade voort te gaan sodat hulle uiteindelik 'n veel swaarder straf kry en moontlik sterf in 'n rooftog, terwyl die persoon wat aanvanklik gevang en gestraf is onder die straf tot bekering kan kom. Maar al sou so 'n straf uiteindelik vir 'n persoon tot seën wees, verander dit niks aan die feit dat dit wel as 'n straf van God op sy sonde oor hom gekom het.

So is dit ook met VIGS omdat dit hoofsaaklik langs die weg van oortreding van God se gebooie opgedoen word. As daar nie so 'n direkte verband tussen VIGS (en trouens ook ander seksueel oordraagbare-siektes) en die oortreding van God se gebod op seksuele gebied was nie, sou 'n mens in die lig van die boek Job en van Johannes 9:1-3 nie sonder meer kon sê dat dit 'n straf van God op die sonde is nie.

Dit is ook die siening van Douma. Hy (1987:34) sê dat VIGS 'n oordeel van God is oor 'n manier van lewe wat heeltemal in stryd is met die bestemming wat God aan die liggaam en gees van die mens gegee het. Volgens hom (1987:32-33) kan 'n mens by VIGS van God se oordeel praat omdat dit uit die Bybel duidelik is hoe die mens geskape is en met watter doel hy 'n liggaam ontvang het. Daarom is hy ook daarvan oortuig dat mense wat VIGS deur buitehuwelikse heteroseksuele of homoseksuele geslagsgemeenskap opgedoen het, hulleself skuldig moet voel (1987:31). 
Den Toom (1988a/1988b) het skerp op hierdie siening van Douma gereageer. Hy verwerp dit radikaal. Volgens hom (1988b:10) kan VIGS nie as 'n straf of oordeel van God gesien word nie omdat die oorsaak van VIGS nie by God lê nie, maar by 'n virus. Hy is ook van oordeel (1988a:13-14) dat die oordeelsaankondigings en strafdreigings in die Skrif nie letterlik bedoel is nie, maar bloot pedagogies verstaan moet word.

Den Toom se siening is heeltemal onaanvaarbaar omdat dit duidelik in stryd is met die belydenis van die voorsienigheid van God (Heidelbergse Kategismus Sondag 10). Trouens, volgens Den Toom se siening is daar in werklikheid géén plek vir God in die lewe van die moderne mens nie, omdat alles wat gebeur aan natuurlike oorsake toegeskryf kan word. Daarby bring sy siening ook die Skrifgesag ernstig in gedrang.

Hoewel VIGS dus by mense wat dit deur 'n seksueel losbandige lewe opgedoen het, gesien moet word as 'n straf op hulle sondige lewe, kan dit nie sonder meer gesê word van mense wat VIGS nie deur'n sondige lewe opgedoen het nie, maar dit gekry het sonder dat hulle daarvoor aanspreeklik gehou kan word. VIGS kan byvoorbeeld nie as straf beskou word in die volgende gevalle nie: die hergebruik van onhigiëniese spuitnaalde, of as ' $n$ man wat losbandig lewe en VIGS opdoen, deur sy geslagsgemeenskap met sy vrou wat kuis lewe, die siekte ook aan haar oordra. In so 'n geval moet 'n mens dit sien as ' $n$ groot beproewing vir die betrokkenes en hulle naasbestaandes.

\subsubsection{Die reikwydte van God se straf}

As 'n mens meedoen aan seksuele praktyke wat deur God verbied word en VIGS as gevolg daarvan opdoen, moet steeds in gedagte gehou word dat die reikwydte van God se straf dikwels veel verder strek as die skuldige individu.

Dit kan duidelik gesien word in die geskiedenis van Jona. Hy sondig deur ongehoorsaamheid aan God se bevel om na Nineve te gaan. God straf hom deur die storm op see. Maar nie net hy word getref deur die straf nie, maar ook die "onskuldiges" wat saam met hom aan boord is (Jona 1). Agan is 'n ander voorbeeld (Jos. 7). Hy sondig deur die diefstal van goedere by die inname van Jerigo. Daardeur bring hy die oordeel van God oor die hele Israel wat tot gevolg het dat 36 "onskuldiges" sterf toe Israel Ai probeer inneem het.

Dieselfde geld vir die persoon wat aan sondige seksuele handelinge meedoen en as gevolg daarvan VIGS opdoen. Dit kan daartoe lei dat die persoon se eggenoot/eggenote deur normale geslagsgemeenskap in die huwelik ook VIGS opdoen en dat ' $n$ kind of kinders gebore word wat ook besmet is. En al sou dit nie gebeur nie, word daar in elk geval 'n skaduwee oor die ander lede van sy/haar gesin gebring. Indien die per- 
soon voortgaan met die losbandige seksuele lewe, dra hy/sy in elk geval die VIGS-virus ook oor aan ander persone - al kan hulle dan nie as "onskuldiges" beskou word nie.

Uit 'n Christelike oogpunt beskou, moet ook hierdie aspek van die betrokkenes se optrede as onverantwoordelik en oneties bestempel word.

In die positiewe eis van die sesde gebod volgens die Heidelbergse Kategismus (antw. 107) word onder andere gesê: "God ... gebied ... dat ons ons naaste moet liefhê soos onsself. Ons moet ... alles wat hom kan benadeel, sover moontlik probeer voorkom."

Van die liefde wat die Christen teenoor sy naaste moet hê, sê Paulus (Rom. 13:10): "Die liefde doen die naaste geen kwaad nie."

As bogenoemde uitspraak in die Kategismus en dit wat Paulus in Romeine 13 sê in een sin saamgevat moet word, kan dit soos volg geformuleer word: die liefde doen die naaste geen kwaad nie maar probeer juis om te voorkom dat enigiets hom kan benadeel of kwaad kan aandoen (De Bruyn, 1982:361-362).

Indien 'n mens die ongeoorloofde seksuele bedrywighede waardeur VIGS opgedoen en versprei kan word met al die gevolge wat dit vir die persoon self, sy/haar gesin en ander mense kan hê in hierdie lig beskou, is dit duidelik dat ander mense (om nie van homself/haarself te praat nie) ontsettende kwaad aangedoen kan word - dermate dat hulle letterlik in lewensgevaar kan kom. Daarom is so 'n optrede volgens Christelike beginsels oneties.

\subsection{Etiese beoordeling van mense se gedrag teenoor VIGS-lyers}

Dit het geblyk dat as mense VIGS opdoen en dit word bekend, die gemeenskap daarop reageer deur hulle aan die betrokke persone te onttrek (Louw, 1988:71). Enersyds is dit miskien omdat hulle nie geassosieer wil word met die sedelose lewe waarvan die VIGS-lyers verdink word nie. Maar andersyds is ' $n$ belangriker rede dat hulle vrees dat enige kontak met VIGS-lyers tot gevolg kan hè dat hulle self VIGS kan opdoen (Hartmann, 1987:10). Dit kan tot gevolg hê dat die VIGS-lyers gestigmatiseer en verwerp word en heeltemal vereensaam. Hulle word dan uitgeworpenes van die samelewing wat van oordeel is dat die VIGS-lyers self verantwoordelik is vir die ellende waarin hulle verkeer en eintlik gekry het wat hulle verdien.

So 'n houding en optrede is vir die Christelike etiek onaanvaarbaar omdat dit in stryd is met die gebod van God tot naasteliefde. Volgens die eis van God in sy Woord (Matt. 7:12; 22:39; Luk. 10:25-37) moet hierdie mense met bewoënheid en deernis 
gehelp word, nie net dié wat VIGS opgedoen het sonder dat hulle self daarvoor verantwoordelik is nie, maar ook dié wat in die VIGS wat hulle onder lede het die verskriklike konsekwensies van hulle eie sondige lewe sien.

Wie 'n hoogmoedige houding teenoor die VIGS-lyers inneem en op hulle neersien, moet onthou dat Paulus, nadat hy in Romeine 1:18-32 gewys het op die toorn en straf van God teenoor volhardende sondaars, direk daarna in Romeine 2:1 die volgende sê: "Daarom is daar vir jou geen verontskuldiging nie, vir jou, mens wat 'n ander veroordeel, wie jy ook al is. Deurdat jy oor 'n ander 'n oordeel uitspreek, veroordeel jy jouself, want jy wat veroordeel, doen dieselfde dinge."

In die optrede van gelowiges teenoor VIGS-lyers sal iets van die barmhartigheid van Christus teenoor sondige mense moet uitstraal. Aan hulle sal ook verkondig moet word dat daar volkome vergewing van sondes is vir dié wat waarlik in Christus glo.

Die wyse waarop die VIGS-lyers in hulle nood bygestaan moet word, moet deur die vakgebied Pastoraal aangedui word. Daarin sal wel daarmee rekening gehou moet word dat terwyl die VIGS-lyers gehelp word, die samelewing teen verdere verspreiding van VIGS beskerm moet word. Die Etiek wil slegs beklemtoon dat die VIGS-lyers bygestaan moet word en nie alleen in die koue gelaat mag word nie.

Aan die ander kant moet die VIGS-lyer ook sy etiese roeping verstaan. Hy moet bewustelik so optree dat hy niemand anders besmet nie. Hy moet veral waak teen die gevoel om wraak te neem op die gemeenskap deur doelbewus ander mense te probeer besmet (Louw, 1988:73). Die beginsels van die Christelike etiek geld immers ook vir hom.

\section{DIE ROEPING VAN DIE KERKE}

\subsection{Die prediking}

In die lig van die dreigende VIGS-epidemie moet die kerke in die verkondiging van die Woord in al die fasette van die kerklike lewe baie duidelik wys op die eis van God dat daar maar net een plek is vir geslagsgemeenskap en dit is binne die duursame verbintenis van man en vrou in die monogame huwelik. (Vgl. punt 3.1.2; Verschoor, 1990:17,29.) So 'r kuise lewe is noodsaaklik nie bloot omdat VIGS op die wyse bekamp kan word nie, maar primèr omdat God dit van die mens eis - al het VIGS die eis geradikaliseer. En dit is 'n ope vraag of sekere teoloë en kerke nie indirek vir die verspreiding van VIGS aanspreeklik gehou kan word nie omdat hulle met geslagsgemeenskap buite die huwelik en met homoseksualiteit stilswyend genoeë geneem het 
of dit openlik verdedig het en selfs amptelik goedgekeur het. (Vgl. Robinson, 1966:125-126; Barczay, 1967:213-218; Rinzema, 1972:134; Fletcher, 1974:104, 139,140,146; Lehmann, 1976:136-137; Nederlandse Hervormde Kerk, 1972:65-66,70; Star, 1970:59-60; Rothuizen, 1972:20-21.)

\subsection{Oproep tot verootmoediging}

Die ontsettende, wêreldwye bedreiging wat VIGS vir die mens inhou én die feit dat daar tot dusver geen geneesmiddel daarvoor gevind kon word nie, dwing die mens om te erken dat hy met al sy vermoëns en vaardighede in 'n doodloopstraat beland het. ' $n$ Situasie is bereik waar geen mens meer kan help nie, net God alleen kan. In die lig daarvan behoort die kerke wêreldwyd mense op te roep tot ware bekering en verootmoediging voor God sodat hulle Hom kan smeek om sy ontferming. Natuurlik moet dit nie gedoen word om van God 'n blote noodhulp te mak nie, maar in die besef dat Hy uiteindelik die enigste hulp in nood is (Ps. 50:15). Wat vir die mense onmoontlik is, is vir God wel mooontlik (Mat. 19:26).

\subsection{Hulp aan VIGS-lyers}

In die lig van wat in punt 3.2 gesê is behoort dit duidelik te wees dat daar van kerklike kant in verskeie opsigte hulp aan VIGS-lyers gebied moet word.

Pastorale begeleiding van die VIGS-pasiënte is uiters noodsaaklik (Louw, 1988:66-79). Daarin sal die vergewing van sondes - ook die sondes wat tot VIGS aanleiding gegee het - aan hulle verkondig moet word. Daarin sal hulle ook daarop gewys moet word dat hulle op pad is na 'n nuwe lewe op 'n nuwe aarde onder 'n nuwe hemel waar daar geen pyn en lyde en VIGS sal wees nie. Hieruit is dit duidelik dat die pastorale begeleiding van die VIGS-pasiënt tot 'n groot mate uit sterwensbegeleiding sal bestaan (Van Wyk, 1990:12).

Verder sal ook diakonale hulp met die nodige deernis aan die VIGS-lyer gebied moet word sodat die barmhartigheid van God in Christus aan skuldige mense ook op dié wyse vir hom konkrete gestalte kry.

Binne die gemeenskap van die heiliges sal elke lidmaat die VIGS-lyer in liefde moet bystaan en dra sodat hy nie vereensaam nie. En in 'n sekere sin kan dit sonder onnodige angs en vrees gebeur omdat VIGS nie maklik aansteek nie, solank kontak met die vloeistowwe van die liggaam vermy word. 


\section{SAMEVATTING: ETIESE KONSEKWENSIES VAN VIGS}

VIGS het duidelik aan die lig gebring hoe groot die omvang van losbandige seks in die wêreld is. En aangesien geslagsgemeenskap volgens die Woord van God slegs binne die wettige huwelik van man en vrou mag plaasvind, het VIGS gevolglik ook getoon in hoe 'n mate die wil van God op seksuele gebied tans in die wêreld in ongehoorsaamheid geminag word.

VIGS het die mens laat sien dat hierdie ongehoorsaamheid aan die gebod van God op seksuele gebied verantwoordelik kan wees vir een van die grootste rampe wat die mensdom nog ooit getref het. Daarom dwing VIGS mense om in die aangesig van die dood na te dink oor die konsekwensies van hulle optrede op seksuele gebied vir hulleself en hulle medemens.

VIGS toon duidelik aan dat die eksperimentele benadering tot seks en die praktyk waarvolgens seks een van die belangrikste elemente van 'n genotmoraal of sportmoraal of ontspanningsmoraal geword het, dodelike vrugte voortgebring het. Op dié wyse beklemtoon VIGS opnuut dat seks slegs werklik veilig is as dit binne die duursame struktuur van die huwelik plaasvind waar eros binne die kaders van filia en agape funksioneer. Daaruit is dit ook duidelik dat in God se beperking van geslagsgemeenskap slegs tot die huwelik daar nie alleen groot wysheid opgesluit is nie, maar dat daarin ook sy liefde vir die mens geopenbaar word. Daarom is dit vir die mens se eie beswil dat hy hom hou aan dié wyse voorskrifte van God.

Waar VIGS opgedoen word deur buitehuwelikse geslagsgemeenskap, heteroseksueel of homoseksueel, moet dit gesien word as God se straf op die sonde van seksuele losbandigheid. Waar dit opgedoen word op 'n ander wyse as deur die oortreding van God se gebod, is dit vir die betrokkenes 'n groot beproewing.

VIGS dwing 'n mens tot die besef dat, vanweë die onderlinge verbondenheid van 'n gesin of 'n samelewing, die reikwydte van God se straf oor die sonde dikwels veel verder strek as die individu wat oortree het. Ook om hierdie rede is 'n losbandige seksuele lewe waardeur VIGS opgedoen kan word, oneties.

VIGS dwing die gelowiges om hulle Christelike roeping van daadwerklike naasteliefde teenoor hulle medemens te besef, selfs in gevalle waar mense self vir hulle toestand verantwoordelik is - ook in gevalle waar versigtigheid aan die dag gelê moet word om self nie besmet te raak nie. In hierdie unieke situasie het die kerk van die Here 'n unieke roeping wat hy nie mag verwaarloos nie. 


\section{BIBLJOGRAFIE}

ANON. 1989. VIGS: sprake van God se oordecl en penade. Die Kerkbode, 143(17):1,2 Mei 5.

BARCZAY, G. 1967. Revolution der Moral? Die Wandlung der sexualnormen als Frage an die evangelische Ethik. Znrich/Stullgarı : Zwingli Verlag.

BARNES, A. 1847. Notes, explanatory and practical, on the epistle to the Romans. London : William Tegg.

BENNETT, M. BENNETT, REBECCA. 1989. Sex the big risk. The Plain Truth, 54(4):3-4. April 6.

BRILLENBURG WURTH, G. 1956. De straf: haar elhisch en psychologisch aspect. Kampen : Kok.

BRILLENBURG WURTH, G. 1963. Schuld en straf in het licht van de Bijbelse verkondiging. Baarn : Bosch \& Keuning.

COETZEE, J.C., DE KLERK, A.J. \& FLOOR, L. 1980. Die hermeneuse van dic Skrif met die oog op hedendaagse kerklik-etiese vaagstukke. In die. Skriflig, 14(54):12-26. Junie.

D'ASSONVILLE, V.E. 1999. VIGS - 'n siekte wat in die donkel loeslaan (Ps. 91). Die Kerkblad, 92(2833):6. Desember 20.

DE BRUYN, P.J. 1982. Vonthuwelikse geslagsgemeenskap; 'n teologies-etiese studie. (Ongepubliseerde proefskrif (Th.D.) -PU vir CHO.)

DE BRUYN, PJ. 1985. Verantwonde nuerskap. Polchefsiroom : Calvyn-Jubileumbockelonds.

DE RRUYN, P.J. 1989. Die huwelik: wat sê die Bybel daarvan? Potchefsıroom: PU vir CHO, Wetenskapsleer.

DEN TOOM, W. 1989a, 1988b. Straf en zegen. Evangelisch Commentaar, 6(5):11,13-14 Maart 11; 6(6):10-11. Maart 25.

DEN TOOM, W. 1988h. Siraf en zegen. Evangelisch Commentaar, 6(6):10-11. Maarl 25.

DOUMA, J. 1977. Homofilie. Amsterdam : Ton Rolland

DOUMA, J. 1987. AIDS - meer dan ecn riekle. Kampen : Van den Berg.

ELOFF, F.F. 1989? VIGS. Hammanskraal: Unibook.

FLETCHER, J. 1974. Silualion el hics: the new morality. London : SCM Press

FLOOR, L. 1979. Het gericht van God volgens hel Nieuwe Tesiament. Amsterdam : Buijicn \& Schipperheijn.

GOSLINGA, CJ. 1956, De boeken Samuel - 2. Korle Verklaring der Heilige Schrif, Kampen : Kok

GREIJDANUS, S. 1946. Schrifbeginselen ter Schrifluerklaring en historisch overzicht over theorieen en wijzen van Schrifluillegging. Kampen : Kok.

GREljoanus, S. 1953. De briel van den aposiel Paulus a an de Galaten; 3de druk. Korte Verklaring det Heilige Schrift. Kampen : Kok

GROSHEIDE, F.W. 1929. Hermeneutiek ten diensie van de besiudeering van het Nieuwe Testament Kampen : Kok

GROSHEIDE, F.W. 1954. Paulus' eersie brief aan die kerk van Korinıhe. Korte Verklaring der Heiligc Schrift. Kampen : Kok.

HARTMANN, H. 1987. AIDS: de kerken een 7ng ...? Evangelisch Commentaar, 5(1):9-11. Jan 9.

HENDRIKSEN, W. 1979. Galatians; 3rd prinling. New Teslament Commentary. Edinburgh :The Banner of Truth Trusi.

HENDRIKSEN, W. 1980. Romans - 1: chaplers 1-8. New Tesiament Commentary. Edinburgh : The Banner of Truth Trusı.

JANSEN, B.C. 1990. Die heker en siektes: 'n valstrik vir gelowiges in die nagmaal? Die Kerkblad $93(2840) \cdot 9-11$, April 4.

KROEZE, J.H. 1961. Het hoek Job. Commentaar op het Oude Testament. Kampen : Kok.

LANGONE, J. 1989. VIGS: die feile. Kaapslad : Tafelberg.

LEHMANN, P.L. 1976. Ethics in a Christian conlex: 2de druk. New York: Harper \& Row.

LEKKER Ker Ker, A.F.N. 1974. De brief van Paulus aan de Romeinen - 1; 3de druk. De Prediking van het Nieuwe Testament. Nijkerk: Callenbach 
LOUW, D.J. 1988. VIGS: die radikale siekte met 'n uitdaging aan die pastoralc bediening. Nederduitse Gereformeerde Teologiese Tydskrif, 19(1):66-79.

NEDERLANDSE HER VORMDE KERK. 1972. Liefde en sexualiteit; pastorale handreiking, aanvaard door de generale synode der Nederlandse Hervormde Kerk op 20 juni 1972. 's-Gravenhage : Bockencentrum.

Bockencentrum.
PIENAAR, DELENE. 1989/1990. VIGS en die kerk. Die Voorligter, 53(1):50-51. Des. 1989/Jan. 1990.

PRETORIUS, P.J. \& PRETORIUS, D. 1987. Ken en voorkom VIGS: inligting oor en bespreking van verworwe immuniteitsgebrek-sindroom. Potchefstroom : Wesvalia.

RIDDERBOS, H.N. 1954. The epistle of Paul to the churches of Galatia; 2nd ed. The New London Commentary on the New Testament. London/Edinburgh : Marshall, Morgan \& Scott.

RIDDERBOS, H. 1959. Aan de Romeinen. Commentaar op het Nieuwe Testament. Kampen : Kok.

RIDDERBOS, H. 1966. Paulus: ontwerp van zijn theologie. Kampen : Kok.

RIDDERBOS, N.H. 1962. De Psalmen -1. Korte Verklaring der Heilige Schrift. Kampen : Kok.

RINZEMA, J. 1972. De sexuele revolutie: uildaging en antwoord. Kampen : Kok.

ROBINSON, J.A.T. 1966. Eerlijk voor God. Amsterdam : Ten Have.

ROTHUIZEN, G. Th. 1972. Hoe verder? Ethisch-hermeneutische overwegingen. (In Gereformeerde Kerken Nederland: Over mensen die homofiel zijn. Kerkinformatie van de Gereformeerde Kerken in Nederland, 2(1):21-22, Jan 1972.)

SHELP, E.E. \& SUNDERLAND, R.H. 1987. AIDS and the church. Philadelphia : Westminster Press.

STAR, J. 1970. The Presbyterian debate over sex. Look:54,59-60, Nov. 8.

SUNDERLAND, R.H. \& SHELP, E.E. 1987. AIDS: a manual and pastoral care. Philadelphia : Westminster Press.

VAN VEEN, J. 1972. Wat zegt de Bijbel over homofilie. Dordrecht : Drukkerij Dekkers.

VAN WYK, J.H. 1990. VIGS en moraliteit. (In Van Wyk, J.H. \& Verschoor, J. VIGS. Potchefstroom: PU vir CHO. Instituut vir Reformatoriese Studie, Studiestuk nr. 267:1-16.)

VELEMA, W.H. 1978. De rechtvaardiging van de straf; een ethische benadering. Amsterdam : Ton Bolland.

VERSCHOOR, J. 1990. VIGS: vanuit biochemiese perspektief. (In Van Wyk, J.H. \& Verschoor, J. VIGS. Potchefstroom : PU vir CHO. Instituut vir Reformatoriese Studie, Studiestuk nr. 267:17-29.)

WOUTERS, D.N. 1987. AIDS: een testcase voor de kerk. Kampen : Kok. ZAHN, D. TH. 1910. Der Brief des Paulus an die Römer. Kommentar zum Neuen Testament. Leipzig :
Deichert. 
